\title{
Aldosterone Disrupts the Intercellular Flow of Glucose in Cardiac Muscle
}

\author{
Walmor C. De Mello* \\ School of Medicine, University of Puerto Rico, San Juan, PR, USA
}

The activation of the renin-angiotensin system is known to impair intercellular communication in the heart, but the role of aldosterone on the process of chemical communication and particularly the intercellular diffusion of glucose between cardiomyocytes is not known. This problem was investigated in cell pairs isolated from the left ventricle of adult Wistar Kyoto rats. For this, fluorescent glucose was dialyzed into one cell of the pair using the whole cell clamp technique, and its diffusion from cell-to-cell through gap junctions was followed by measuring the fluorescence intensity in the dialyzed as well as in non-dialyzed cell as a function of time. The results indicated that (1) in cell pairs exposed to aldosterone (100 nM) for $24 \mathrm{~h}$, the intercellular flow of glucose through gap junctions was disrupted; (2) although the mechanism by which aldosterone disrupts the cell-to-cell flow of glucose is multifactorial, two major factors are involved: oxidative stress and PKC activation; (3) the effect of aldosterone was significantly reduced by spironolactone (100 nM); and (4) calculation of gap junction permeability (Pj) indicated

OPEN ACCESS

Edited by:

Gaetano Santulli, University of Naples "Federico II", Italy

Reviewed by:

Anastasios Lymperopoulos, Nova Southeastern University, USA Cristina Moreno Vadillo, Maastricht University, Netherlands

*Correspondence:

Walmor C. De Mello

walmor.de-mello@upr.edu

Specialty section: This article was submitted to Cellular Endocrinology, a section of the journal Frontiers in Endocrinology

Received: 15 September 2015 Accepted: 27 November 2015 Published: 11 December 2015

Citation: De Mello WC (2015) Aldosterone Disrupts the Intercellular Flow of Glucose in Cardiac Muscle. Front. Endocrinol. 6:185. doi: 10.3389/fendo.2015.00185 an average values of $0.3 \pm 0.001 \times 10^{-4} \mathrm{~cm} / \mathrm{s}(n=31)$ (four animals) for controls and $24 \pm 0.03 \times 10^{-6} \mathrm{~cm} / \mathrm{s}(n=34)$ (four animals) $(P<0.05)$ for cell pairs exposed to aldosterone $(100 \mathrm{nM})$ for $24 \mathrm{~h}$. Bis-1 $\left(10^{-9} \mathrm{M}\right)$, which is a selective PKC inhibitor, added to the aldosterone solution, improved the value of $\mathrm{Pj}$ to $0.21 \pm 0.001 \times 10^{-4} \mathrm{~cm} / \mathrm{s}(n=24)$ $(P<0.05)$, whereas spironolactone $(100 \mathrm{nM})$ added to aldosterone solution, reduced significantly the effect of the hormone on junctional permeability to glucose.

Keywords: aldosterone, gap junction permeability, glucose heart

\section{HIGHLIGHTS}

- Aldosterone inhibits the cell-to-cell diffusion of glucose in heart.

- Spironolactone inhibits the effect of aldosterone.

- The gap junction permeability is drastically reduced by aldosterone.

- Oxidative stress is involved in the effect of aldosterone.

\section{INTRODUCTION}

Aldosterone is normally involved in the regulation of blood volume and blood pressure. In the last decades, evidence has been provided that the hormone has many effects independently of its regulatory role on blood volume. Aldosterone, for instance, binds to the mineralocorticoid receptor (MR), which resides predominantly in the cytoplasm. Upon ligand binding, the MR acts as a transcription factor generating cardiac remodeling, including hypertrophy and fibrosis (1-5), especially 
during heart failure - an effect blocked by spironolactone (6). Moreover, the hormone enhances the expression of Ang II AT1 receptors in ventricular muscle by twofold (3), an effect inhibited by eplerenone (4), and it is involved in a proliferative response through increased expression of p53-bing protein (7). During pathological conditions, such as myocardial infarction, the production of aldosterone in the cardiac muscle is enhanced, (5) and the cardiac levels of Ang II are increased (7). Both aldosterone and Ang II are involved in the increase of collagen deposition during myocardial infarction [see Ref. (8)], creating a severe impairment of ventricular relaxation and impulse propagation with generation of cardiac arrhythmias. Transcription effects of aldosterone take more than $3 \mathrm{~h}$, whereas rapid non-genomic effects of the hormone can occurs within minutes. Signaling pathways related to the rapid MR/aldosterone responses include the MAPK family and protein kinase C (PKC) (9) as well as intracellular levels of calcium, cAMP, and nitric oxide $(10,11)$.

Clinical trials involving patients with heart failure revealed that MR antagonists reduces morbidity and mortality (6) even when the circulating levels of aldosterone are within normal range, highly suggesting that the activation of local renin-angiotensin aldosterone system (RAAS) is an important contributor factor during heart failure. Other clinical studies showed that elevated plasma aldosterone levels facilitate the development of insulin resistance by increasing oxidative stress and by changing insulin signaling with consequent decrease of glucose transport. Furthermore, enhanced aldosterone levels are associated with myocardial infarction and stroke (12).

Cardiac cells are communicated through gap junction channels which are composed of two oligomers and each oligomer is a connexon which contains connexins (13). Connexin $43(\mathrm{Cx} 43)$ is the main connexin present in cardiac muscle. Connexins contain four transmembrane domains with the amino and carboxyl termini on the cytoplasmic side. The intercellular channels make possible the spread of ions and electrical current from cell-to-cell, which is essential for the electrical synchronization in the heart (14), and is also involved in the intercellular diffusion of amino acids, nucleotides, hormones, and other small molecules up to $1 \mathrm{kDa}$ contributing to the metabolic cooperation between cells $(15,16)$. Aldosterone reduces the expression of connexin 43 (Cx43), which is the main connexin in cardiac muscle (17). Recently, it was found that glucose flows from cell-to-cell through gap junctions in cardiac muscle (16), which indicates that cardiomyocytes share this energy substrate and cooperate metabolically $(16,18)$. No information is available if aldosterone influences the intercellular diffusion of glucose. These observations might have important implications for heart failure, hypertension, and diabetes when the RAAS is activated. In this work, this problem was investigated in ventricular myocytes isolated from adult Wistar Kyoto rats.

\section{MATERIALS AND METHODS}

Normal adult Wistar Kyoto rats were used. The animals were kept in the Animal House at constant temperature $\left(24^{\circ} \mathrm{C}\right)$ and humidity following the recommendations of NIH. Animals were kept on a normal laboratory animal diet and given tap water ad libitum. The animals were anesthetized with $43 \mathrm{mg} / \mathrm{kg}$ of ketamine plus
$5 \mathrm{mg} / \mathrm{kg}$ of xylazine, and the heart was removed with the animals under deep anesthesia. All animal procedures were approved by the IACUC.

\section{Cell Isolation Procedure}

The heart was removed and immediately perfused with normal Krebs solution containing (millimolar): $\mathrm{NaCl}$ - 136.5; $\mathrm{KCl}$ - 5.4; $\mathrm{CaCl}_{2}$ - 1.8; $\mathrm{MgCl}_{2}-0.53 ; \mathrm{NaH}_{2} \mathrm{PO}_{4}-0.3$; $\mathrm{NaHCO}_{3}$ - 11.9; glucose - 5.5; HEPES - 5, pH adjusted to 7.3. After $20 \mathrm{~min}$, a Ca-free solution containing $0.4 \%$ collagenase (Worthington Biochemical Corp.) was recirculated through the heart for $1 \mathrm{~h}$. The collagenase solution was washed out with $100 \mathrm{ml}$ of recovery solution containing (millimolar): taurine 10 , oxalic acid 10, glutamic acid 70, $\mathrm{KCl} 25, \mathrm{KH}_{2} \mathrm{PO}_{4}$ 10 , glucose 10, and EGTA 0.5; pH 7.4. All solutions were oxygenated with $100 \% \mathrm{O}_{2}$. Ventricles were minced (1-2 mm thick slices) and the resulting solution was agitated gently and the suspension was filtered. The filtrate was centrifuged for $4 \mathrm{~min}$ at $22 \times g$. The cell pellets were then resuspended in normal Krebs solution.

\section{Experimental Procedures}

All experiments were performed in a small chamber mounted on the stage of an inverted phase-contrast microscope (Diaphot, Nikon). Ventricular cells were placed in a modified cultured dish (volume $0.75 \mathrm{ml}$ ) in an open-perfusion microincubator (Model PDMI-2, Medical Systems). Cells were allowed to adhere to the bottom of the chamber for $15 \mathrm{~min}$ and were superfused with normal Krebs solution $(3 \mathrm{ml} / \mathrm{min})$ that permits a complete change of the bath in $<500 \mathrm{~ms}$. A video system made possible to inspect the cells and the pipettes throughout the experiments. The electrical measurements were carried out using the patch clamp technique in a whole cell configuration using an Axon (model 200B) patch-clamp amplifier and Digidata 1400 (Molecular Devices, CA, USA).

\section{Measurements of Intercellular Diffusion of Glucose}

Cell pairs of ventricular myocytes were used. Suction pipettes were pulled from microhematocrit tubing by means of a controlled puller (Narashige, Japan) and filled with a solution with the following composition (millimolar): cesium aspartate $120, \mathrm{NaCl} 10$, $\mathrm{MgCl}_{2}$ 3, EGTA 10, tetraethylammonium chloride 20, $\mathrm{Na}_{2}$ ATP 5, and HEPES 5; pH 7.3. In some experiments, fluorescent glucose (molecular weight $180 \mathrm{Da})(4 \%)$ was added to the pipettes. The pipette was attached to one cell of the pair, a gigaohm seal was achieved and then the membrane was ruptured by a brief suction allowing the fluorescent glucose to diffuse from the pipette into the cell.

\section{Measurements of Cell Width}

Measurements of cell width - a major component of cardiac cell volume variation - were made in quiescent ventricular myocytes incubated for $24 \mathrm{~h}$ with Krebs solution containing aldosterone (100 nM), an inverted phase-contrast microscope (Nikon), and a high-resolution camera (Paxcam). Cell width was measured 
using Image J software (150 randomly chosen cells/well, NIH, Bethesda, MD, USA).

\section{Measurements of Oxidative Stress}

To directly monitor real-time reactive oxygen/nitrogen species (ROS/RNS), a kit including an oxidative stress detection reagent (ENZO Life Sciences, Farmingdale, NY, USA) was used. Measurements of fluorescence intensity were made in controls and in cells exposed to aldosterone $(100 \mathrm{nM})$ for $24 \mathrm{~h}$. The oxygen/nitrogen species kit was added for $30 \mathrm{~min}$ and the green fluorescence was measured again using a wide filed fluorescence microscope equipped with standard green $(490 / 525 \mathrm{~nm})$ filter set.

\section{Influence of PKC Inhibition}

The influence of PKC activation on the effect of aldosterone was investigated. For this, cell pairs were exposed to aldosterone $(100 \mathrm{nM})$ plus Bis-1 $\left(10^{-9} \mathrm{M}\right)$, which is a selective inhibitor of PKC. After $24 \mathrm{~h}$, fluorescent glucose was dialyzed into cell pairs as described above and cell-to-cell diffusion of glucose was followed as a function of time.

\section{Drugs}

Aldosterone and spironolactone were from Sigma Chemical Co., Saint Louis, MO, USA. Bis-1 was from Calbiochem.

\section{Statistical Analysis}

Data are expressed as mean \pm SEM. Student's $t$-test was used. Differences were considered significant when $P<0.05$.

\section{RESULTS}

\section{Aldosterone Disrupts Intercellular Flow of Glucose}

Previous observations indicated that in the normal heart, glucose flows from cell-to-cell through gap junctions (16). To investigate the influence of aldosterone on the intercellular diffusion of glucose, cell pairs isolated from the left ventricle of normal Wistar Kyoto rats were used. Fluorescent glucose was dialyzed into one cell of the pair and its diffusion through the gap junction was followed by measuring the fluorescence intensity in both cells of the pair as a function of time. As shown in Figures $\mathbf{1}$ and 2, in cell pairs exposed to aldosterone $(100 \mathrm{nM})$ for $24 \mathrm{~h}$, the intercellular movement of glucose was drastically reduced. Exposure of the cell pairs to aldosterone ( $100 \mathrm{nM}$ ) for $15 \mathrm{~min}$ did not change the junctional permeability to glucose (not shown).

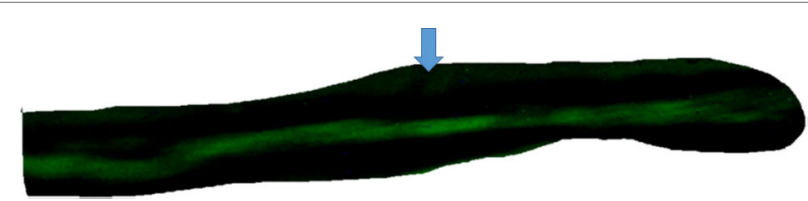

FIGURE 1 | Top - absence of intercellular diffusion of fluorescent glucose in single cell pair exposed to aldosterone (100 nM) for $24 \mathbf{~ h}$. Arrow indicates site of micropipette filled with glucose.

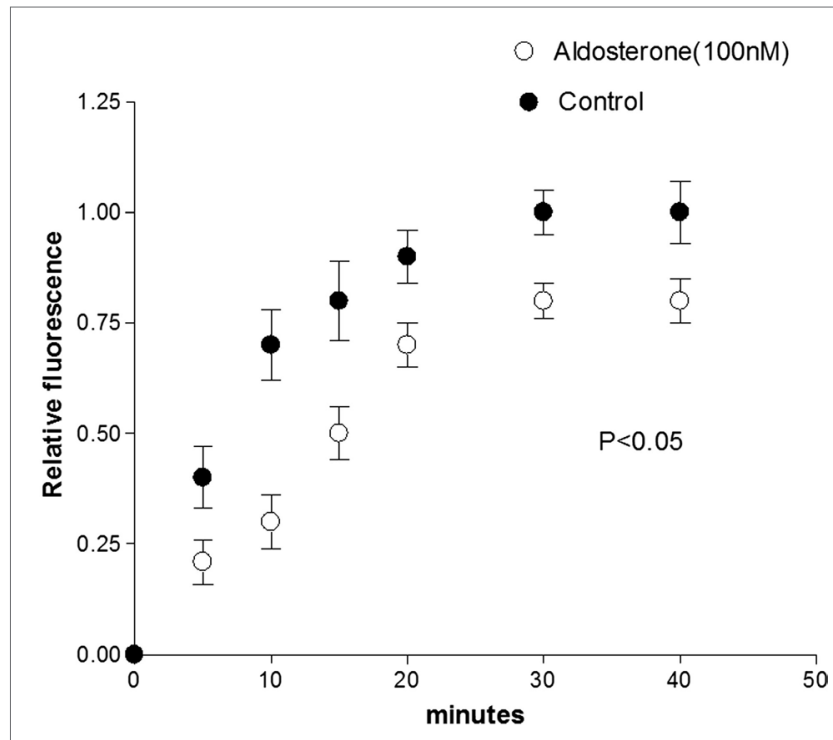

FIGURE 2 | Inhibition of cell-to-cell diffusion of fluorescent glucose in cell pairs exposed to aldosterone (100 $\mathrm{nM}$ ) for $\mathbf{2 4} \mathrm{h}$. Each point is the average from 25 cell pairs (four animals) isolated from the left ventricle. Vertical line at each point SEM $(P<0.05)$.

To investigate the role of the MRs on the effect of aldosterone, cell pairs were exposed to aldosterone $(100 \mathrm{nM})$ plus spironolactone $(100 \mathrm{nM})$ for a period of $24 \mathrm{~h}$. Measurements of intercellular diffusion of glucose performed at the end of this time indicated that spironolactone reduces the effect of aldosterone on the intercellular flow of glucose as shown in Figure 3.

\section{Effect of Aldosterone on Cell Width}

Because cell swelling is known to cause a decline of gap junction permeability (19), it is important to investigate if the hormone changes the cell volume of cardiac cells. To investigate this possibility, measurements of cell width were performed in absence and after $24 \mathrm{~h}$ of exposure to aldosterone (100 nM). Figure 4 shows that aldosterone increases the cell width significantly, while spironolactone (100 nM) added to aldosterone solution reduced significantly the effect of the hormone on cell width.

\section{Role of Oxidative Stress}

Oxidative stress induced by the activation of MR is known to cause diastolic dysfunction and ventricular hypertrophy in rats (20). To investigate the possible role of oxidative stress on the decoupling action of aldosterone, isolated cells were incubated with Krebs solution containing aldosterone (100 nM) for $24 \mathrm{~h}$ and then exposed to the oxidative stress detection reagent for $30 \mathrm{~min}$. Measurements revealed that the green fluorescence intensity inside the cells was significantly increased in cells incubated with aldosterone when compared with controls (see Figures 5 and 6).

In some experiments, measurements of reactive species were performed in presence of an inhibitor of ROS/RNS (ENZO Life Sciences). The results revealed a significant decline of green fluorescence elicited by aldosterone (100 nM). Moreover, measurements of gap junction permeability to glucose performed 


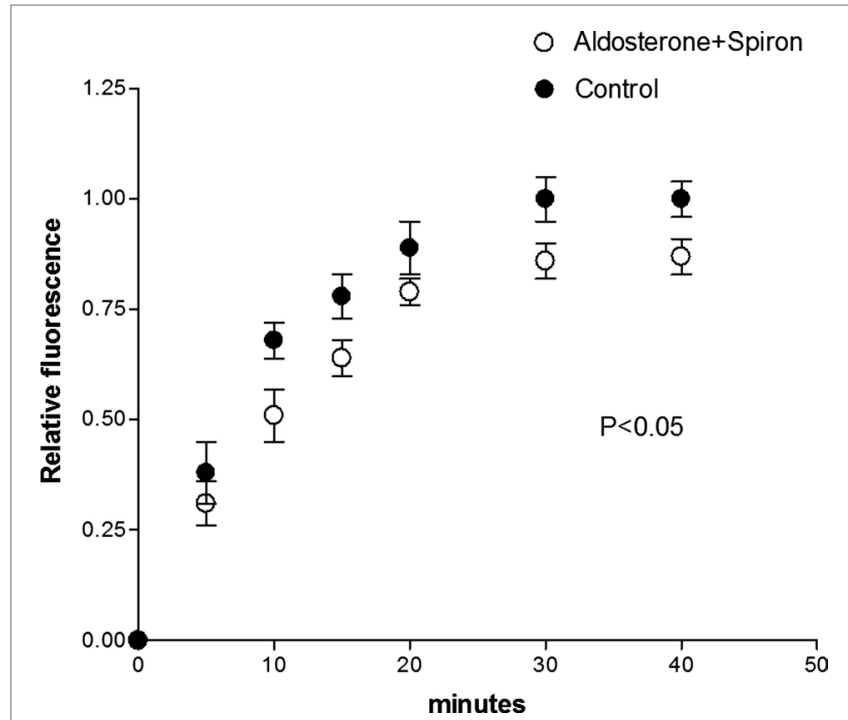

FIGURE 3 | Spironolactone (100 nM) added to aldosterone (100 nM) solution reduced the effect of aldosterone on the intercellular flow of glucose. Each point is the average from 26 cell pairs. Vertical line at each point SEM $(P<0.05)$

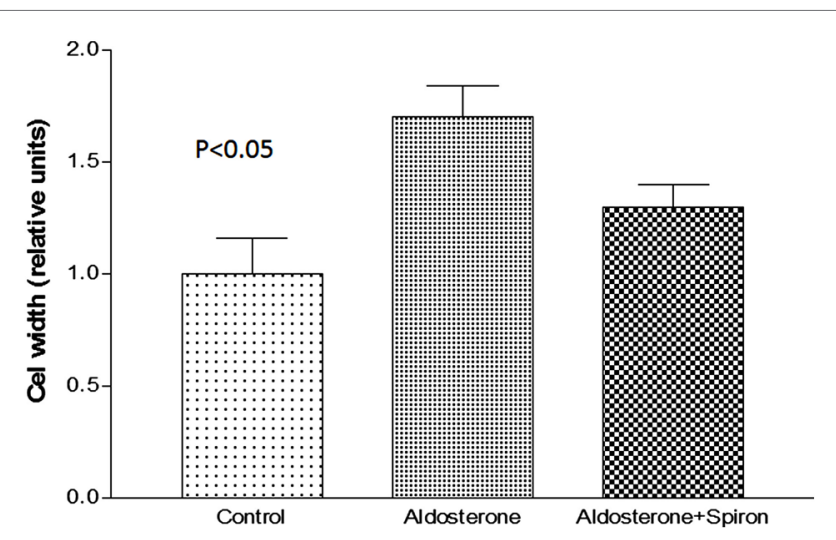

FIGURE 4 | Increase of cell width elicited by aldosterone (100 nM) and the effect of spironolactone $(100 \mathrm{nM})$ on cell swelling induced by aldosterone. Each bar is the average from 20 cells. Vertical line at each bar SEM $(P<0.05)$

under these conditions indicated larger values of junctional permeability, $\mathrm{Pj}=0.1 \pm 0.002 \times 10^{-4} \mathrm{~cm} / \mathrm{s}(n=12)(P<0.05)$.

\section{Role of PKC Inhibition}

Previous findings revealed that activation of PKC and consequent phosphorylation of connexin 43 decreases the dye coupling between cells increasing the preponderance of lower values of single channel conductance and permeability $(21,22)$. These observations led us to investigate if aldosterone reduces the gap junction permeability to glucose by activating PKC. For this, Bis1 , which is an inhibitor of PKC $\left(10^{-9} \mathrm{M}\right)$, was added to aldosterone solution and after $24 \mathrm{~h}$ fluorescent glucose was dialyzed into the
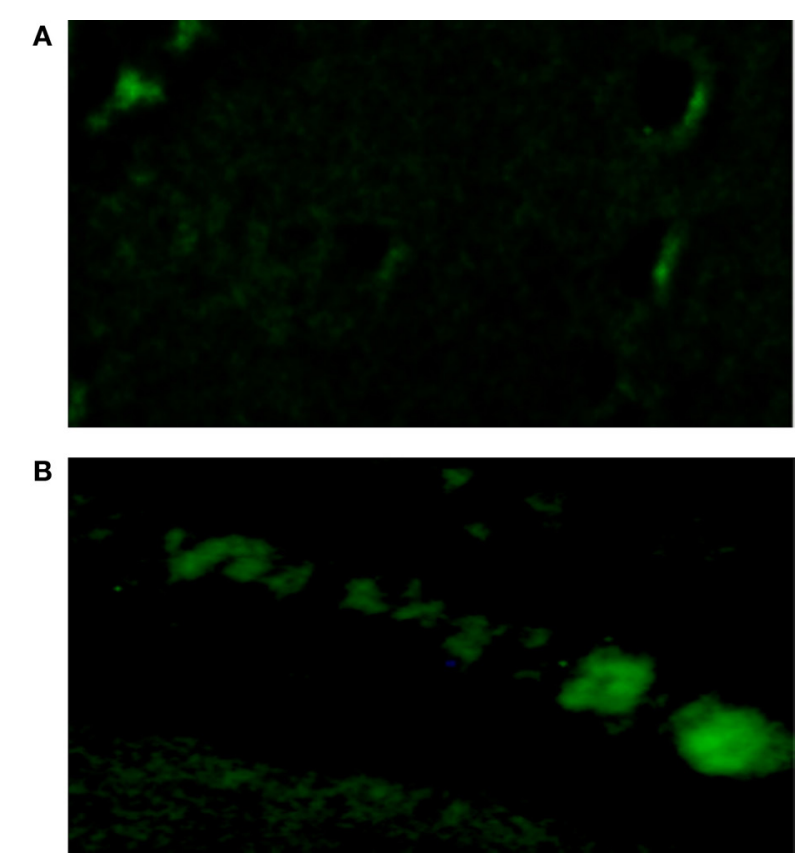

FIGURE 5 | Influence of aldosterone on oxidative stress. (A) Control fluorescence microscopy of single cell under control conditions, left bottom; (B) green fluorescence measured in the same cell after administration of aldosterone (100 $\mathrm{nM})$.

cell, and its intercellular diffusion was followed as a function of time. The results from several experiments indicated that the PKC inhibitor reduces drastically the effect of aldosterone on junctional permability (see Figure 7).

\section{Quantitative Measurements of Gap Junction Permeability}

A quantitative estimation of the gap junction permeability to glucose $(\mathrm{Pj})$ was made using the following equation (23):

$$
\mathrm{Pj}=\mathrm{Vcell} / \mathrm{Aj} \times \mathrm{Kj}
$$

where Vcell is the cell volume that is accessible to glucose, $\mathrm{Aj}$ is area of the gap junctional membrane, and $\mathrm{Kj}$ is the rate constant of the transjunctional diffusion (23). Morphometric studies performed on ventricular tissues (24) indicate that Aj contributes to $17 \%$ of the cross sectional area of the rat cardiomyocyte $\left(177 \mathrm{~mm}^{2}\right)$ and the myofibrils, mitochondria, sarcoplasmic reticulum, and nucleus occupies about $88 \%$ of the total cell volume leaving $12 \%$ of total cell volume free for the diffusion of glucose through the cytoplasm. The junctional permeability to glucose $(\mathrm{Pj})$ was then calculated for controls and for cell pairs exposed to aldosterone $(100 \mathrm{nM})$ or to aldosterone $(100 \mathrm{nM})$ plus spironolactone $(100 \mathrm{nM})$ for $24 \mathrm{~h}$. As shown in Table 1, $\mathrm{Pj}$ calculated for the controls taken Vcell as $12 \%$ of total cell volume was equal to $0.3 \pm 0.001 \times 10^{-4} \mathrm{~cm} / \mathrm{s}$ $(n=31)$ (four animals). An appreciable decrease of junctional permeability was found in cell pairs exposed to aldosterone $(100 \mathrm{nM})\left[24 \pm 0.03 \times 10^{-6} \mathrm{~cm} / \mathrm{s}(n=34)\right.$ (four animals) 


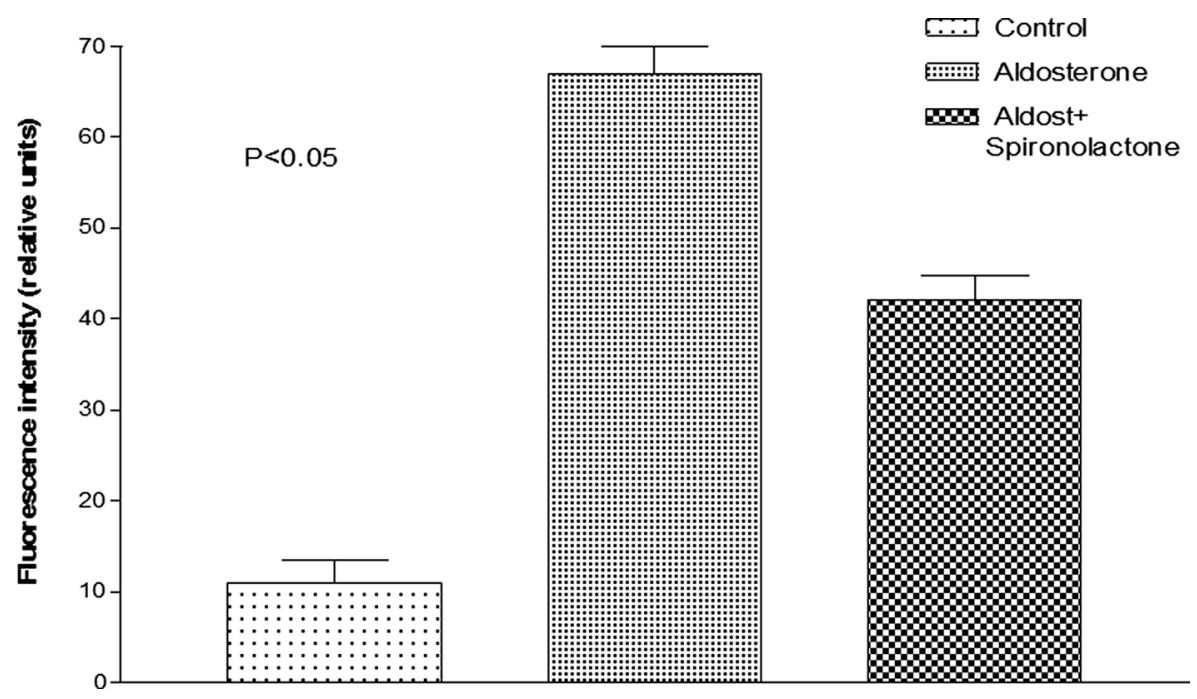

FIGURE 6 | Influence of aldosterone on oxidative stress. Each bar is the average from 23 ventricular myocytes (4 animals). Vertical line at each bar SEM $(P<0.05)$.

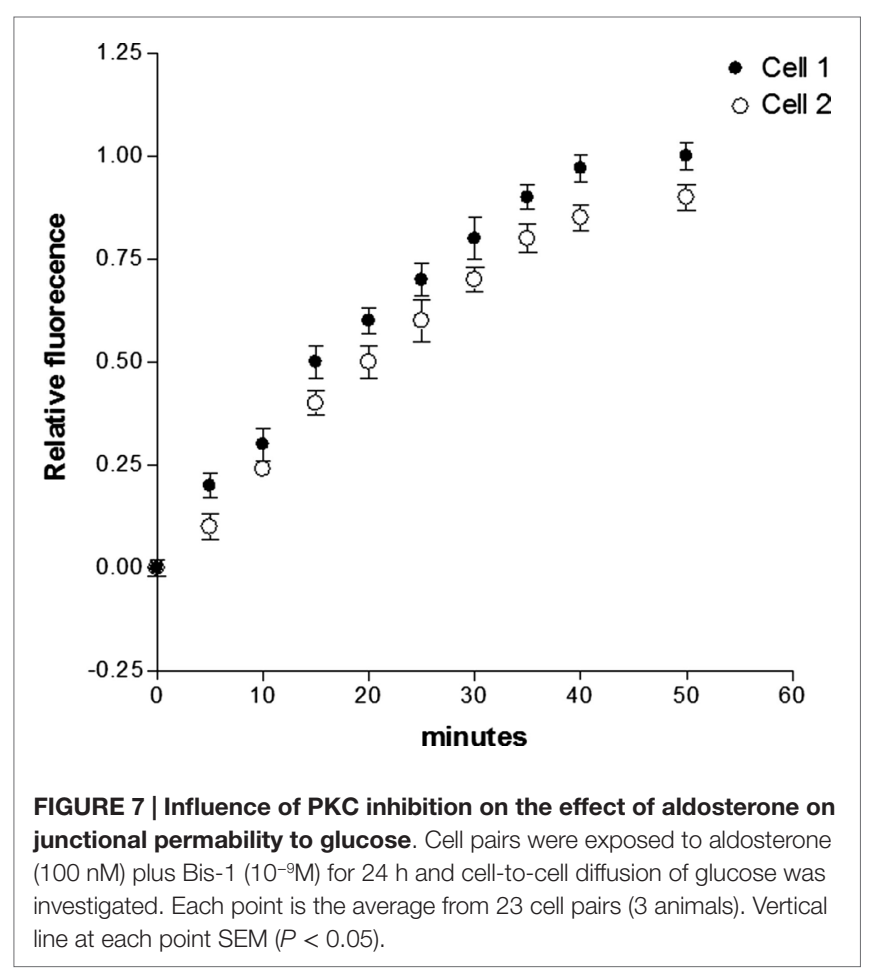

$(P<0.05)]$ taking $12 \%$ of the total volume, which was assumed $60 \%$ larger than the controls due to cell swelling (see Table 1). In cell pairs exposed to aldosterone plus spironolactone (100 $\mathrm{nM}$ ), the value of $\mathrm{Pj}$ was significantly greater than that achieved with aldosterone alone (see Table 1). The value of junctional permeability $(\mathrm{Pj})$ in presence of Bis-1 $\left(10^{-9} \mathrm{M}\right)$ and aldosterone $(100 \mathrm{nM})$ was $0.21 \pm 0.0011 \times 10^{-4} \mathrm{~cm} / \mathrm{s}(n=24)$ $(P<0.05)$.
TABLE 1 | Influence of aldosterone alone and aldosterone (100 nM) plus spironolactone $(100 \mathrm{nM})$ on the gap junction permeability $(\mathrm{Pj})(\mathrm{cm} / \mathrm{s})$ to glucose.

\begin{tabular}{lll}
\hline Control & Aldosterone & \multicolumn{1}{c}{$\begin{array}{c}\text { Aldosterone plus } \\
\text { spironolactone }\end{array}$} \\
\hline $0.3 \pm 0.001 \times 10^{-4}$ & $24 \pm 0.003 \times 10^{-6}$ & $\begin{array}{l}2.4 \pm 0.004 \times 10^{-5} \\
(n=29)(4 \text { animals })\end{array}$ \\
$(n=31)(4$ animals $)$ & $(n=34)(4$ animals $)$ & $P<0.05$ \\
& $P<0.05$ &
\end{tabular}

Cells were exposed to aldosterone or aldosterone plus spironolactone for $24 \mathrm{~h}$.

\section{DISCUSSION}

The present results indicated, for the first time, that aldosterone disrupts chemical communication and the intercellular diffusion of glucose in the normal heart - an effect related to the activation of the MR. Since Ang II is known to release aldosterone by the adrenal gland, it is possible to conclude that the activation of the RAAS is involved in the regulation of intercellular diffusion of glucose in the heart. The mechanism by which the MR activation disrupts the cell-to-cell diffusion of glucose seems complex and multifactorial (see Figure 5) mainly involving the generation of oxidative stress, the downregulation of connexin43 (Cx43) (17), which is the main connexin in the heart and PKC activation. Aldosterone might contribute to the deterioration of chemical coupling by activation ERK, JNK, and p38 MAPKs (25). On the other hand, the effect of the hormone on the intracellular ion regulation (26) cannot be discarded. It is known, for instance, that aldosterone, rapidly increases $\left[\mathrm{Na}^{+}\right] \mathrm{i}$ and cell volume via $\mathrm{Na}^{+}$ $\mathrm{K}^{+} 2 \mathrm{Cl}^{-}$cotransporter $(\mathrm{NKCCl})$ and $\mathrm{Na}^{+} / \mathrm{H}^{+}$exchange (NHE) (26). An increment of cell width was indeed, found in cells exposed to aldosterone for $24 \mathrm{~h}$ (see above). Since cell swelling decreases the gap junction permeability (19), it is conceivable 
that the cell swelling induced by aldosterone contributes to the disruption of cell-to-cell diffusion of glucose as described above.

Concerning the possible effect of ald osterone on the expression of $\mathrm{Cx} 43$, previous observations revealed that the downregulation of Cx43 expression elicited by aldosterone was not suppressed by eplerenone (17). Other studies indicated that spironolactone reverses gap junction remodeling during ventricular hypertrophy (27). Since spirinolactone decreased significantly the effect of aldosterone on the intercellular flow of glucose, the contribution of a decline in $\mathrm{Cx} 43$ remodeling to the disruption of intercellular movement of glucose cannot be ruled out.

It is known that phosphorylation of gap junction proteins including connexin43, which is the main connexin in cardiac muscle, leads to a decrease of gap junction permeability and conductance $(21,22)$. On the other hand, evidence is available that aldosterone induces cellular effects through activation of PKC [see Ref. (28)] and that PKC activation may result from oxidative stress or lead to ROS generation. Indeed, PKC-dependent phosphorylation of Ser368 in Cx43 decreases intercellular coupling due to altered junctional permeability (29). These findings might indicate that the decline of intercellular flow of glucose caused by aldosterone is related to oxidative stress-induced PKC activation as shown in Figures 7 and 8.

Although it is well established that aldosterone produces MR-mediated injury, the hormone mediates part of Ang II-induced cardiac injury and gene expression suggesting a cross-talk between the hormone and the peptide. Previous studies showed that high glucose impairs the intercellular flow of glucose due, in part, due to the increased Ang II levels inside the cells $(16,18)$. Moreover, the enhanced synthesis of aldosterone during myocardial infarction is mediated by Ang II AT1 receptors $(3,30)$, and beta arrestin generated locally plays a role in Ang II-mediated aldosterone production (31). It is then reasonable to think that Ang II generated by the activation of the RAS can contribute to the decoupling action of aldosterone as described above by activating PKC and inducing oxidative stress.

It is known that not only aldosterone but also cortisol can cause cell death during MI $(32,33)$ indicating an important role of glucorticoids. Since no studies were included on the influence of cortisol on the intercellular diffusion of glucose, further observations will be needed to clarify this point.

Previous observations showed that mitochondria oxidative stress contributes to Ang II-induced gap junction remodeling (34) and that mitochondria can generate aldosterone (35). These findings might indicate that the mitochondria oxidative stress participates in the deterioration of chemical communication between heart cells. It is known that aldosterone, for instance, causes intramitochondrial $\mathrm{Ca}^{2+}$ overloading and oxidative stress with opening of the mitochondrial permeability transition pore (36). Although mitochondrial ROS has an important role in normal physiological cell signaling, overproduction of mitochondrial ROS elicited by high glucose as well as Ang II and hypoxia, lead to cardiovascular damage. Therefore, the possible role of mitochondrial ROS on the inhibition of intercellular glucose diffusion elicited by aldosterone cannot be discarded.

The interruption of intercellular transfer of glucose elicited by aldosterone has important consequences for tissue homeostasis and ATP synthesis. A reduction of the Na pump, for instance, results in an increment of the intracellular sodium concentration and membrane depolarization with consequent change of cardiac excitability. It is known that aldosterone generates triggered activity caused by early-afterdepolarization (EAD) and delayed afterdepolarization (DAD), which is associated with intracellular $\mathrm{Ca}^{2+}$ mishandling (37). Transgenic mice with cardiac-specific MR overexpression show prolonged ventricular repolarization and severe arrhythmia associated with a decrease of outward potassium current (38) and abnormal $\mathrm{Ca}^{2+}$ release from the sarcoplasmic reticulum during diastole with consequent generation of cardiac arrhythmias (37). Since an increase of intracellular

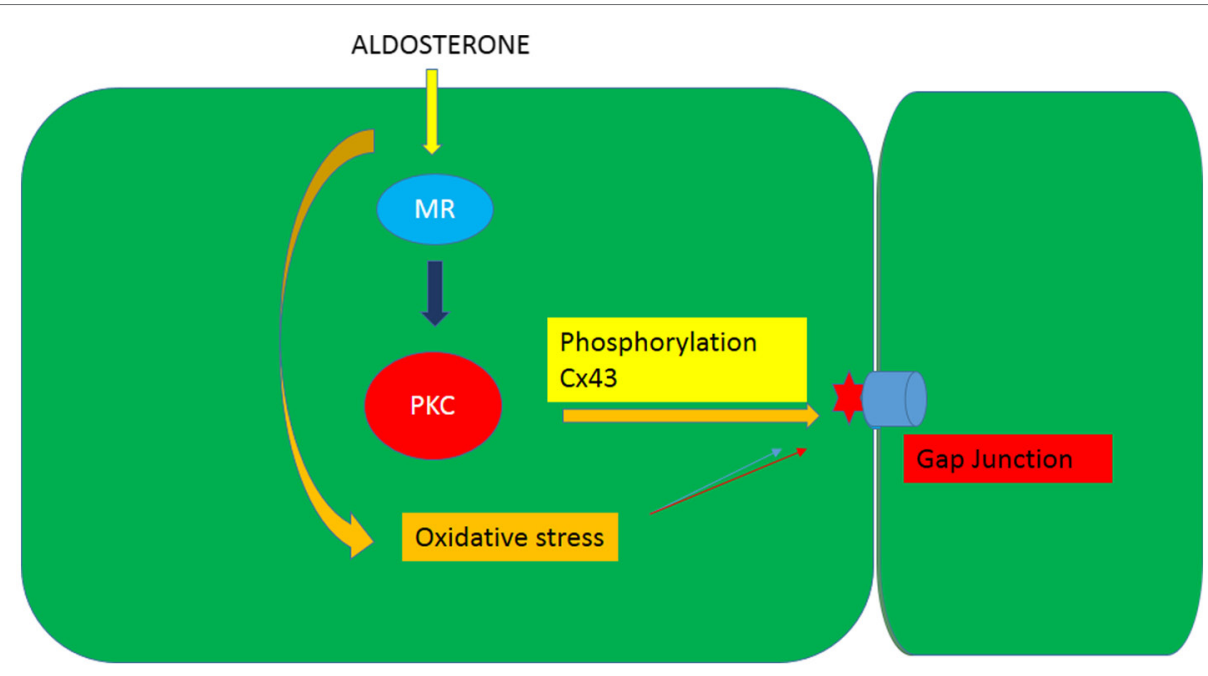

FIGURE 8 | Diagram illustrating the influence of aldosterone on the junctional permeability (Pj) to glucose through the generation of oxidative stress an activation of PKC 
calcium concentration is known to impair heart cell communication (14), one cannot rule out the possibility that the increment of intracellular $\mathrm{Ca}^{2+}$ contributes to the decrease of junctional permeability to glucose as described above.

The disruption of cell-to-cell diffusion of glucose elicited by aldosterone generates discrepant intracellular levels of glucose with consequent variation of ATP synthesis resulting in different energy levels with serious consequences for cellular function. The interruption of intercellular flow of glucose might be particularly harmful for the failing or diabetic heart in which the cardiac cell energy is already reduced and the transport of glucose through the surface cell membrane is impaired. The physiological consequences of interruption of intercellular diffusion of glucose in the heart are not known and require further studies.

\section{Limitations of the Present Studies}

(1) Although the present measurements of oxidative stress indicated its contribution to the effect of aldosterone on the intercellular diffusion of glucose, further studies using stronger inhibitors of oxidative stress will be needed to confirm the present findings.

(2) The physiological consequences of the disruption of glucose transport through gap junction are not known. A possible result of this disruption is the generation of different

\section{REFERENCES}

1. Pierce P, Funder JW. High affinity aldosterone binding sites (type 1 receptors) in rat heart. Clin Exp Pharmacol Physiol (1987) 14:859-86. doi:10.111 1/j.1440-1681.1987.tb02422.x

2. Lombes M, Oblin ME, Gase JM, Baulieu EE, Framan N, Bouvalet JP. Immunohistochemical and biochemical evidence for a cardiovascular mineralocorticoid receptor. Circ Res (1992) 71:503-10. doi:10.1161/01.RES.71.3.503

3. Robert V, Heymes C, Silvestre JS, Sabri A, Swynghedauw B, Delcayre Angiotensin C. AT1 receptor subtype as a cardiac target of aldosterone: role in aldosterone-salt induced fibrosis. Hypertension (1999) 33:981-6. doi:10.1161/01.HYP.33.4.981

4. De Mello WC, Gerena Y. Eplerenone inhibits the intracrine and extracellular actions of angiotensin II on the inward calcium current in the failing heart. On the presence of an intracrine renin angiotensin aldosterone system. Regul Pept (2008) 151:1-3. doi:10.1016/j.regpep.2008.06.003

5. Silvestre JR, Robert V, Heymes C, Aupetit-Faisant B, Monas C, Moalic JM, et al. Myocardial production of aldosterone and corticosterone in the rat. Physiological regulation. J Biol Chem (1998) 273:4883-91. doi:10.1074/jbc.273.9.4883

6. Pitt B, Zannad F, Remme WJ, Cody R, Castaigne A, Perez A, et al. The effect of spironolactone on morbidity and mortality in patients with severe heart failure. Randomized Aldactone Evaluation Study Investigators. N Engl J Med (1999) 341:709-17. doi:10.1056/NEJM199909023411001

7. Jaffe IZ, Mendelsohn ME. Angiotensin II and aldosterone regulate gene transcription via functional mineralocortocoid receptors in human coronary artery smooth muscle cells. Circ Res (2005) 96:643-50. doi:10.1161/01. RES.0000159937.05502.d1

8. Delcayre C, Heymes C, Milliez P, Swynghedauw B. Throphic effects of aldosterone. In: De Mello WC, editor. Renin Angiotensin System and the Heart. West Sussex: John Wiley and Sons (2004). p. 161-75.

9. Gekle M, Freudinger R, Mildenberger S, Schenk K, Marschitz I, Schramek $\mathrm{H}$. Rapid activation of $\mathrm{Na}+\mathrm{H}+$-exchange in MDCK cells by aldosterone involves MAP-kinase ERK1/2. Pflügers Arch (2001) 1441:781-6. doi:10.1007/ s004240000507 intracellular levels of glucose throughout the ventricle leading to unequal intracellular ATP levels with all the consequences for cellular energetics. Certainly, further studies will be needed to clarify these points.

(3) Although previous studies revealed that aldosterone reduces the expression of $\mathrm{Cx} 43$ in cardiac cells of neonatal rats, similar studies will be necessary to confirm the effect of the hormone in adult-differentiated cardiomyocytes.

\section{CONCLUSION}

Aldosterone disrupts the exchange of glucose between cardiac cells by reducing the gap junction permeability. The mechanism by which aldosterone changes the gap junction permeability is not known but it is probably multifactorial, including changes in cell volume, oxidative stress, and phosphorylation of gap junction proteins. Moreover, a down regulation of $\mathrm{Cx} 43$ (17) might contribute to the disruption of intercellular flow of glucose between the cardiomyocytes, but further studies will be needed to confirm this possibility.

\section{ACKNOWLEDGMENTS}

This work was supported in part by NIH Grant GM61838 and by Institutional Funds.

10. Wehling M. Nongenomic actions of steroid hormones. Trends Endocrinol Metab (1994) 5:347-53. doi:10.1016/1043-2760(94)90165-1

11. Christ M, Wehling M, Kirsch E, Viengchareun S, Zennaro MC, Lombes M. Enhancement of $\beta$-adrenergic cAMP-signaling by the mineralocorticoid receptor. Mol Cell Endocrinol (2005) 231:23-31. doi:10.1016/j.mce.2004.12.004

12. Bender SB, McGraw AP, Jaffe IZ, Sowers JR. Mineralocorticoid receptor-mediated vascular insulin resistance: an early contributor to diabetes-related vascular disease? Diabetes (2013) 62(2):313-9. doi:10.2337/db12-0905

13. Goodeough DE, Goliger JA, Paul D. Connexins, connexons and intercellular communication. Ann Rev Biochem (1996) 65:475-502.

14. De Mello WC. Intercellular communication in cardiac muscle. Circ Res (1982) 51(1):1-9. doi:10.1161/01.RES.51.1.1

15. Gilula NB, Reeves OR, Steinbach A. Metabolic coupling, ionic coupling and cell contacts. Nature (1972) 235:262-5. doi:10.1038/235262a0

16. De Mello WC. Cell-to-cell diffusion of glucose in the mammalian heart is disrupted by high glucose. Implications for the diabetic heart. Exp Cell Res (2015) 334(2):239-45. doi:10.1016/j.yexcr.2015.01.021

17. Suzuki S, Ohkusa T, Sato T, Yoshida M, Yasui K, Miwa K, et al. Effects of aldosterone on $\mathrm{Cx} 43$ gap junction expression in neonatal rat cultured cardiomyocytes. Circ J (2009) 73(8):1504-12. doi:10.1253/circj.CJ-08-1065

18. De Mello WC. Intracellular angiotensin II disrupts chemical communication and impairs metabolic cooperation between cardiac myocytes. Peptides (2015) 72:57-60. doi:10.1016/j.peptides.2015.04.001

19. De Mello WC. Cell swelling impairs dye coupling in adult rat ventricular myocytes. Cell volume as a regulator of cell communication. Mol Cell Biochem (2010) 343(1-2):107-13. doi:10.1007/s11010-010-0504-8

20. Takahashi K, Murase T, Takatsu M, Matsuura N, Nagasawa K, Hattori T, et al. Roles of oxidative stress and the mineralocorticoid receptor in cardiac pathology in a rat model of metabolic syndrome. Nogoya J Med Sci (2015) 77:275-89.

21. Jongsma HJ, van Rijen HVM, Kwak BR. Phosphorylation of connexins: consequences for permeability, conductance and kinetics of gap junction channels. In: Peracchia C, editor. Gap Junctions. New York, NY: Academic Press (2000). p. 131-44. 
22. De Mello WC. Intracellular angiotensin II regulates the inward calcium current in cardiac myocytes. Hypertension (1998) 32:976-82. doi:10.1161/01. HYP.32.6.976

23. Imanaga I. Cell-to-cell coupling studied by diffusional methods in myocardial cells. Experientia (1987) 43:1080-3. doi:10.1007/BF01956043

24. Matter A. A morphometric study of the nexus of cardiac muscle. J Cell Biol (1973) 56:690-6. doi:10.1083/jcb.56.3.690

25. Inoue N, Ohkusa T, Nao T, Lee JK, Matsumoto T, Hisamatsu Y, et al. Rapid electrical stimulation of contraction modulates gap junction protein in neonatal rat cultured cardiomyocytes: involvement of mitogen-activated protein kinases and effects of angiotensin II-receptor antagonist. J Am Coll Cardiol (2004) 44:914-22. doi:10.1016/S0735-1097(04)01122-2

26. Matsui S, Satoh H, Kawashima H, Nagasaka S, Niu CF, Urushida T, et al. Non-genomic effects of aldosterone on intracellular ion regulation and cell volume in rat ventricular myocytes. Can J Physiol Pharmacol (2007) 85:264-73. doi:10.1139/Y07-017

27. Qu J, Volpicelli FM, Garcia LI, Sandeep N, Zhang J, Márquez-Rosado L, et al. Gap junction remodeling and spironolactone-dependent reverse remodeling in the hypertrophied heart. Circ Res (2009) 104:365-71. doi:10.1161/ CIRCRESAHA.108.184044

28. Winter C, Kampik NB, Vedovelli L, Rothenberger F, Paunescu TG, Stehberger $\mathrm{PA}$, et al. Aldosterone stimulates vacuolar $\mathrm{H}(+)$-ATPase activity in renal acid-secretory intercalated cells mainly via a protein kinase C-dependent pathway. Am J Physiol Cell Physiol (2011) 301(5):C1251-61. doi:10.1152/ajpcell.00076.2011

29. Ek-Vitorin JF, King TJ, Heyman NS, Lampe PD, Burt JM. Selectivity of connexin 43 channels is regulated through protein kinase C-dependent phosphorylation. Circ Res (2006) 98:1498-505. doi:10.1161/01.RES.0000227572.45891.2c

30. Silvestre JS, Heymes C, Oubénaïssa A, Robert V, Aupetit-Faisant B, Carayon A. Activation of cardiac aldosterone production in rat myocardial infarction: effect of angiotensin II receptor blockade and role in cardiac fibrosis. Circulation (1999) 99(20):2694-701. doi:10.1161/01.CIR.99.20.2694

31. Lymperopoulos A, Rengo G, Zincarelli C, Kim J, Soltys S, Koch WJ. An adrenal beta-arrestin 1-mediated signaling pathway underlies angiotensin II-induced aldosterone production in vitro and in vivo. Proc Natl Acad Sci U S A (2009) 106(14):5825-30. doi:10.1073/pnas.0811706106

32. Mihailidou AS, Loan Le TY, Mardini M, Funder JW. Glucocorticoids activate cardiac mineralocorticoid receptors during experimental myocardial infarction. Hypertension (2009) 54(6):1306-12. doi:10.1161/ HYPERTENSIONAHA.109.136242

33. Hirata A, Maeda N, Hiuge A, Hibuse T, Fujita K, Okada T, et al. Blockade of mineralocorticoid receptor reverses adipocyte dysfunction and insulin resistance in obese mice. Cardiovasc Res (2009) 84:164-72. doi:10.1093/cvr/ cvp191

34. Sovari AA, Rutledge CA, Jeong EM, Dolmatova E, Arasu D, Liu H. Mitochondria oxidative stress, connexin43remodeling, and sudden arrhythmic death. Circ Arrhythm Electrophysiol (2013) 6(3):623-31. doi:10.1161/ CIRCEP.112.976787

35. Peters J, Wanka H, Peters B, Hoffmann S. A renin transcript lacking exon1 encodes for a non-secretory intracellular renin that increases aldosterone production in transgenic rats. J Cell Mol Med (2008) 12:1229-37. doi:10.1111/j.1582-4934.2008.00132.x

36. Shahbaz AU, Kamalov G, Wenyuan Zhao W, Tieqiang Zhao T, Johnson PL, Sun $\mathrm{Y}$, et al. Mitochondria-target cardioprotection in aldosteroenism. J Cardiovasc Pharmacol (2011) 57(1):37-43. doi:10.1097/FJC.0b013e3181fe1250

37. Gómez AM, Rueda A, Sainte-Marie Y, Pereira L, Zissimopoulos S, Zhu X, et al. Mineralocorticoid modulation of cardiac ryanodine receptor activity is associated with downregulation of FK506-binding proteins. Circulation (2009) 119:2179-87. doi:10.1161/CIRCULATIONAHA.108.805804

38. Ouvrard-Pascaud A, Sainte-Marie Y, Bénitah JP, Perrier R, Soukaseum C, Cat AN, et al. Conditional mineralocorticoid receptor expression in the heart leads to life-threatening arrhythmias. Circulation (2005) 111:3025-33. doi:10.1161/ CIRCULATIONAHA.104.503706

Conflict of Interest Statement: The author declares that the research was conducted in the absence of any commercial or financial relationships that could be construed as a potential conflict of interest.

Copyright (c) 2015 De Mello. This is an open-access article distributed under the terms of the Creative Commons Attribution License (CC BY). The use, distribution or reproduction in other forums is permitted, provided the original author(s) or licensor are credited and that the original publication in this journal is cited, in accordance with accepted academic practice. No use, distribution or reproduction is permitted which does not comply with these terms. 